\title{
Islam in Italy: insights from a Europe-Mediterranean perspective
}

\author{
MARIA PARADISO ${ }^{1}$
}

\begin{abstract}
This paper explores the changing role of Islam in Europe, via the case of Italy. The focus is on the contemporary geographies of the changing identities and relationships in the Euro-Mediterranean region. The article intends to challenge the continuous representation of Islam in Europe between homogeneity and otherness. Indeed, the approach considers that relationships which shape places (and are shaped by places) do not stem only from media narratives, from powers and ideologies in general, but also from people's everyday inter-ethnic, inter-cultural, and emotional interactions. The latter do not occur in a vacuum, but rather in places and digital communication channels under grids of power. They are sometimes characterized by behaviours of self-caging and last but not least they always develop in light of geographical transformative power of encounters as 'situated' dynamics of people. Encounters are further shaped and have transformative potential within realms of 'moral geographies' of people and society's values and beliefs while dealing with 'difference'. The paper is based on a series of fieldwork carried out by the author over the years including expert interviews (interreligious dialogue associations, religious leaders, and researchers) and surveys/interviews with immigrants from across the Mediterranean, and on available data and literature for Italy. Main findings for policy-making can be summarized as follows: Europe is a periphery for Umma, not a central place, but in contrast to some origin countries, Islam versions as Islam as predominant not a minority religion. Conversely, the European tradition of human rights, universalism, and democracy should be re-examined and practiced not only in the abstract but in the concrete form of engaged human relations with 'empathy', while laissez faire multiculturalism, aggressive assimilation or 'culturalism' exceptions should be avoided.
\end{abstract}

Keywords: Islam, mobility, assimilation, xenophobia, Italy, Europe, Mediterranean

\section{Introduction}

Taking into account the current scenario of global mobile communications, the paper explores the 'Islam(s)' in Europe, via the case of Italy in a global mobile perspective, as an initial approach to contemporary geographies of the Euro-Mediterranean changing identities and relationships.

The approach in scrutinizing emerging spatialities and networked space considers that relationships which shape places (and are shaped by places) stem not only from media narratives, powers and ideologies in general, but also from everyday people's inter-ethnic, inter-cultural, and emotional interactions. The latter do not occur in a vacuum, but rather in places and digital communication channels under grids of power à la DAtтA, A. (2009), and sometimes with the behaviour of self-caging (EvA, F. 2015). Last but not least, they always occur in light of geographical transformative power of encounters as 'situated' dynamics of people (Valentine, G. and Sadgrove, D. 2012). Encounters are further shaped and have transformative potential within realms of 'moral geographies' of people and society's values and beliefs while dealing with 'difference'. Such interactions are often charac-

\footnotetext{
${ }^{1}$ Department of Economics, Management, Methods, University of Sannio, Piazza Arechi II, 82100 Benevento, Italy. E-mail: paradiso@unisannio.it
} 
terized by blockages of inter-ethnic or intercultural exchanges, as well as by inequalities among people, legacies in political approach and institutions, and emotional geographies in terms of ambitions, hopes, expectations, fears. Thus, the complexity of interconnections - interconnected places and subjectivities - stimulates us going beyond categories which are too reductive of subjectivities and to adhere to Gill Valentine's (2007) approach of 'intersectionality' in terms of belonging and identity construction.

The paper deals with the topic by re-positing it as both a geopolitical imbricate site of encounters and currents: new hegemonic and counter-power discourse(s) and alliances; new identity formation and quest of legitimacy as well as the 'humanistic' locus of (mobile) people's narratives. Altogether pose many implications for European new spatialities and changing relationships (see Kocsis, K. et al. 2016 for assessing mobilities to Europe). Here, mobility is meant in its recent paradigm of both spatial and virtual mobilities of people (Kellerman, A. 2006; Cresswell, T. and Merriman, P. 2011; Montanari, A. and Paluzzi, E. 2016). In addition, the paper conceptually includes mobilities of personal and collective emotions injected in places (Paradiso, M. 2013), the phenomenon of people 'moving' from one religion to another (the 'new Muslims' of Europe), and ideas and discussions in interreligious dialogues and encounters.

In parallel, dynamics of encounter and change are typified by a variety of personal and virtual mobilities in terms of gender, motivations, interreligious dialogue, emotional geographies, and their impacts and circulation rather than a binary origin/destination spatial path. They are also produced, reproduced, and transformed in digital mobile communications.

There is no assumption of 'Islam' as a whole, nor a binary logic à la 'burquini or not burquini'. The challenge and implications are subtler, pervasive and should not be left only to media, Ministers of Interior, or religious leaders' narratives and practices. Instead, geographies of practiced Islam should be scrutinized in light of individuals' mobilities and lives in light of contexts, emotions, encounters, power grids, and emancipation.

The paper is based on a series of field work carried out by the author which included interviews with experts (inter-religious dialogue associations, religious leaders, researchers), questionnaire surveys and interviews with immigrants from throughout the Mediterranean region (Photo 1).

In what follows, this paper first tries to unpack the concept of 'Islam' and its lexical variations. Second, it frames the elements of analysis and interpretations. Third, it highlights the narratives and practices of developing the Italian Islam geography. Then, alternative thinking is presented including voices from the 'inter-religious dialogue' and, author's knowledge from fieldwork in Italy with Muslim migrants and in a Muslim country with migrants from Europe. In the concluding section, the paper proposes some alternatives beyond the binary dialectic à la 'burquini or not burquini', in order to stimulate ideas for better encountering both sides and avoiding social blockages.

\section{Problems of definitions and categorization}

This paper intends to challenge the continuous representation of Islam in Europe between homogeneity in se and otherness vis à vis Europe. This representation happens in this paper's view because the Islamic world is discussed as an unpacked concept with problems of categorization and disrespect of geographical contexts where it develops.

Categorization problems have been increasingly posed by media and sometimes by an irresponsible political manipulation of popular emotional geopolitical imagination after hegemonic violence, images and fundamentalist geopolitical actions. All this is even amplified and exacerbated by the viral digital communication which globally intersect with all geographical space: domestically, nationally, internationally, individually. 


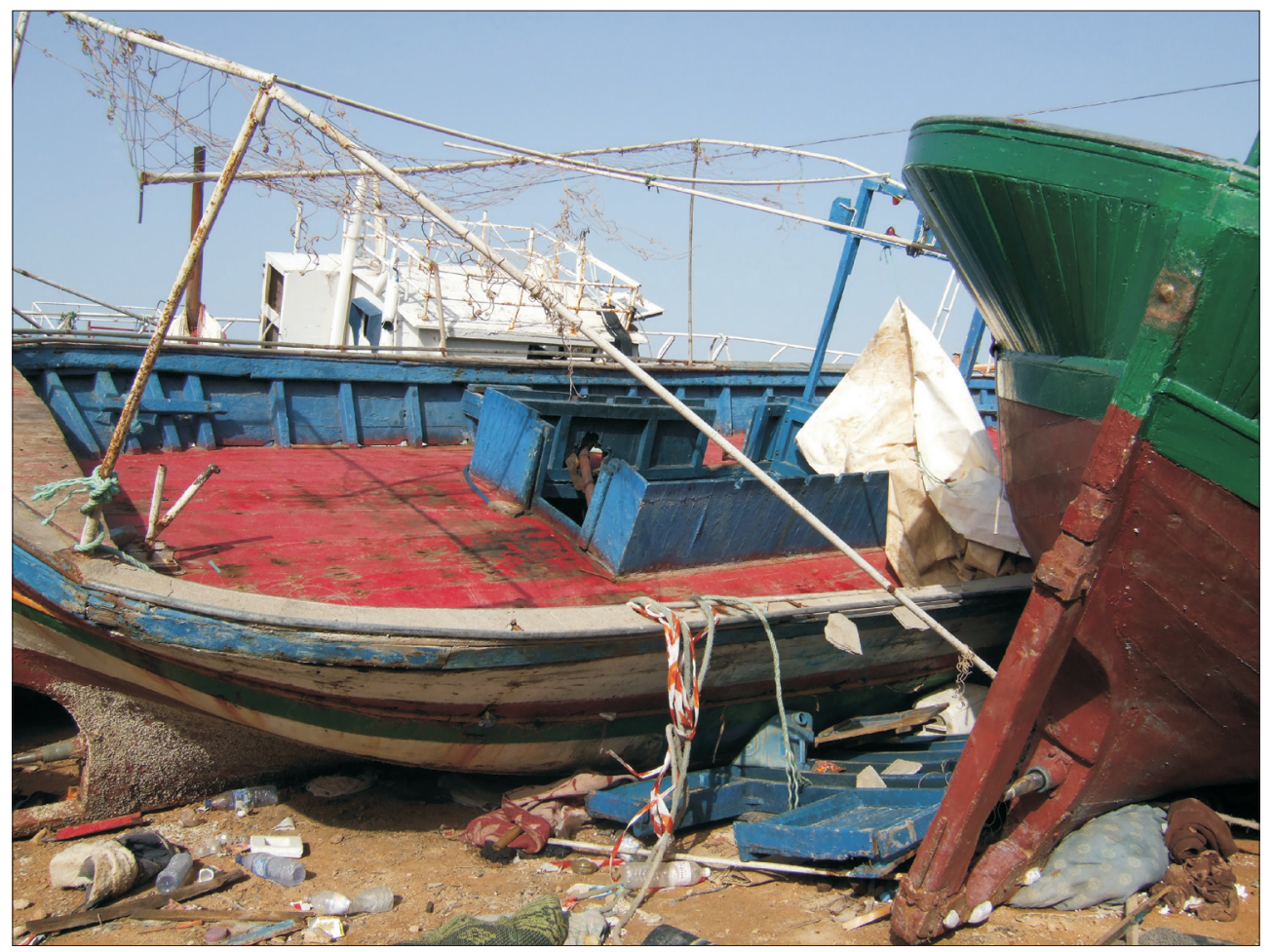

Photo 1. Wrecks of migrants' ships in Lampedusa Island (Photo by Paradiso, M.)

Categories we use to narrate about people who move across space have the potential to inflict epistemological violence (HyNDMAN, J. and Giles, W. 2016 quoted in Еrкhamp, P. 2016). This happens because they can induce problems of 'diorthosis' (FARINELLI, F. 1998). A 'diorthosis' arises when a category mistakenly reduces the diversity of those being categorized. A process of 'diorthosis' stems from a cognitive and operational approach which arrives at a firm judgment about the nature of things and functionality modes before realizing a proper image. Thus, a dissonant geography arises or a conflictual one. This can apply to abstract categories such as 'Islam', 'Western', race...

In contemplating the topic of Islam in Europe, the author was struck by the lexical shift that occurred in very recent years: in Italy the most frequently used words shifted from Muslims and the Muslim world to Islam or 'Islamics' despite the fact that using the word Muslims (musulmani), sometimes in ancient times 'maomettani' (Mahomettans), had been traditional for more than a millennium. On the one hand there is probably an influence of news content in English, where there is a predominance of the use of the word Islam as against Muslim, but on the other hand, satellite TV channels which are based in the Arab peninsula may also influence the wording in that direction.

This is not a neutral language use but, rather, a non-neutral reality distortion. It is far from the traditional cultural and language nuance in Italy: Muslims or Muslim world would drive the attention to people seen in their heterogeneity and individual lives instead of an overwhelming religious belonging under the word 'Islamic'. The word 'Islamics' 
covers under one explanation (religious belonging) all ethnic, personal, class, gender, language, culture, ambitions, customs, emotions, influences of experience on identity construction, relationship, and belonging bonds. These bonds indeed shape human lives and places, but attempting to fit them all under the umbrella of 'Islamic' induces a reduction of meaning and understanding; it borders people, places, meanings, communications, perceptions, anchorages for mutual understanding, acceptance and emancipation.

Moreover, the word Islam is extensively used (and abused) in all violent and criminal propaganda about bloody so-called religious war and terrorism, which produces a process of 'diorthosis' in people's perception of media contents: the reduction of an interpreted religious world to hegemonic and violent ones. Thus, 'diorthosis' reduces rights, bridging points, and emancipation tendencies and, conversely, increases dissonance, violence, closure, and (on both sides) intolerance.

It must also be noted that there is also a good share of migrants who declare no religious belonging when they come to Europe, atheism or not observing status cannot be declared and observed in a predominant Muslim religion country. This per se should avoid the use of Islamic people or Muslim when referring to people coming from MENA countries at large (North African, Maghrebine, Middle East or Mashrek, Turkish people).

A parallel discourse can probably be constructed for racists and xenophobic people and the psychological, socio-economic and personal factors that shape their exclusionary mindset and violence. What are their multiple anchorages in life about if Muslims' identity is reduced to a one and only 'faith' and identity factor? Which factors or forces produce reductions 'ad unum', blockages, or borders? For whom and what?

Thus, the first challenge is to avoid a geopolitical discourse neglecting human variability. Secondly, one should consider 'European' Islam's potential impacts within the 'Umma', internally in Europe and thus globally for 'Umma' in new societies as well as within origin countries' religion.
Thus, comes a first issue for science and 'good' politics: focusing on human subjectivities and multiple belongings (SEN, A. 2006; Malouf, A. 2010), ways of flourishing in new contexts and emancipating from some origin contexts of Islam practice.

The second problem of definition (challenge) is: which Islam is Islam? There is a high degree of ethnic variability in the Islamic world itself, with different 'moral geographies' of Islam and its potential for integration. There is a geopolitical competition within the Sunni/Shiite cleavage and within the Sunni world. Obviously many of these fractures can be softened or mediated by political élites (for example, Moroccan Islam vis à vis Saudi Wahhabism; Sunni-Shia (see PAP, N. and GLied, V. 2017), on the role of political élites in the Hungarian case). Actually, emotional geographies stemmed from satellite TV showing people who are killed by bombing in Iraq, Afghanistan, Syria, Yemen reduced traditional intra-religious borders.

Moreover, there is another stake to Islam internal and external dialectic: European Muslims, former Christians or atheists who became Muslims and precisely their dialectics with their religion, countries of origin and 'Umma' at large.

Therefore, the topic reveals a web of geographic issues oscillating between two poles of geopolitical pressure and human subjectivities of emancipation and identity building. They can be initially critically examined along a series of questions and axis of interpretation summarized in Table 1.

Author spent four months in Morocco and engaged in extensive fieldwork focusing on migrants from Europe, local NGOs, residents, and experts. In addition, she carried out fieldwork in Italy comprising of ca. 200 interviews and 120 questionnaires. This paper builds on this body of work. Interviewed people are kept anonymous (three leaders from Italian Muslim organizations; three people from Nigrizia/Confronti association).

At large, the Islamic community is increasingly considered to be deviating from 'the ordinary body of knowledge' (BERGER, P.I. 
Table 1. Framing questions and axis of interpretation*

\begin{tabular}{c|l}
\hline 1 & $\begin{array}{l}\text { Which Islam from which country? (ethnic variability and geographies of culture, identity, language } \\
\text { of Muslims). }\end{array}$ \\
\hline 2 & $\begin{array}{l}\text { Which Islam from which tradition? Sunni, Shiite? Arab or non-Arab Islam? (Islam of Mosques and } \\
\text { two way relations with the European location). }\end{array}$ \\
\hline 3 & Which Islam from which State? (The issue of Islam of States). \\
\hline 4 & $\begin{array}{l}\text { Migrants brought faith? (issues of migrants' encounter and subjective lived difference; issues of } \\
\text { religious and secularized people). }\end{array}$ \\
\hline 5 & Which generation and where? \\
\hline 6 & What about gender relations and agency? \\
\hline 7 & $\begin{array}{l}\text { New Muslims as Europeans who moved to Muslim faith and implications: what about their dialectic } \\
\text { between their background and feedbacks with country of origin for their religion? (Geopolitics of } \\
\text { change from Europe within Umma). }\end{array}$ \\
\hline
\end{tabular}

${ }^{*}$ Compiled by the author.

1969 quoted in Allievi, S. 1999, 171), thus, a knowledgeable minority because of the weight of religion in shaping human identity in secularized societies such as those in Europe. However, this broad definition includes too many definitional problems (what is the 'ordinary' about?) and too much reductionism. Conversely, it is perhaps a definition which can serve mass media sensationalism. Moreover, this reductionism probably reinforces narrowed self-identification by people with Muslim faith.

These are starting point to argue that there is a differentiated Islam in Europe. Europe is indeed a stake for Islam(s) but in multiple ways not only the supposed 'conquest' one or 'Eurabia'. Simultaneously, Europe is a periphery for 'Umma', not a central place, but the Islam of Europe contradicts some religious versions of Islam as the predominant status (majority religion) tolerating 'dhimma' (minorities) and not as a minority religion. Indeed, Muslims of Europe can induce changes both for European spatialities and identity and push for innovating Muslim world, Islam of States. Currently Muslim people are under enormous geopolitical pressure. Internally, in countries with large immigrant populations, they are facing increasing Islamophobia and xenophobia in a cadre of lacking integration state policies and training about local civic values, language, culture of residence countries or citizenship. Outside Europe,
Muslims are targets, vehicles, tools for geopolitical states' Islam competition, conservative charities and non-governmental entities which perpetuate traditions or allow social spaces' aggregation which 'de facto' increases 'closed' communities. Altogether, this pressure drives Muslim migrants towards ghettoization paths with problems of self-caging and deviance rather than integration.

Conversely, there can be communities set up in Europe to establish stricter communities of observance which are not permitted in their country of origin. One must also remember the case of niche mobilities from Europe to non-European countries for religious training, political and cultural exchanges and converts' organizational political tours both for networking and participation in internationally organized political groups (Allievi, S. 1999).

With these initial conceptual issues, interviews aimed first to raise the question of the rising equivalence in popular language and popular geopolitics visions of the lexical use of Muslims or Islamic: 'what is the difference, if any, between the Islamic and Muslim words' to both Christian and Muslims interviewees in Italy (or in Morocco).

The responses to the question about Islamic variability and wording use can be summarized as follows: 'people are 'the' Muslims, things and institutions are Islamic' (Abdel, nick name for a Moroccan journalist working 
in an interethnic-interfaith dialogue magazine.) Moreover, 'Islam itself is generally brought by mobile people who bring their faith with themselves' (Riccardo, nick name for a person involved in interreligious dialogue and director of a specialized magazine). Incidentally, in the paradigmatic view of mobility, everything changes: the person, the identity, the relationships, the faith itself the origin and destination context, all realms and practices by the mobile person interacting with others.

Summarizing, all the argumentation stigmatizes a simplistic reductionism by media and some politicians of Islam as an unpacked whole: this homogeneity has no neutral or positive effects for society's stability. The human individual freedom of thinking and action margins are reduced in a cage where subjectivity and life are narrowly impoverished along the dominant discourse of faith. Thus, the individual can become victim of a deficit of identity, frustration, and possibly with other factors ground for fanatic Islam as well as his/her interlocutors.

\section{Overall situation of Islam in Italy: data and surveys}

According to the Unar/Idos 2014 report, From Discrimination to Rights, there are about 1.6 million Muslims in Italy. They are the second biggest community of faith after Catholics. The majority of Muslims in Italy are immigrants. This situation greatly affects the relationship of the Italian government with Islam, which, like immigration, is managed by the Ministry of Interior. It is no coincidence that many now-defunct Muslim organizations have been established by Ministers of Interior Pisanu, Amato and Maroni. Immigration and Islam are treated as a single emergency phenomenon and a security issue.

This approach, which combines the two phenomena, is very close to a part of the plural Islamic reality, especially that arc of naturalized and natives converted to
Islam, who denounce a clear violation of the Constitution, which guarantees freedom of worship to all citizens.

\section{Ethnic variability, legitimacy}

This section refers to people from countries with Islamic majorities and an Islamic cultural background. The percentage of Muslims attending mosques varies between 10 and 20 per cent (El Ayoubi, M. 2015); 28.6 per cent consider themselves not practitioners or laic (Gritti, R. and Allam, M. 2001). The distribution of people from Muslim countries in the study included people from Northern Africa, the Middle East, a large proportion of sub-Saharan countries and a growing proportion of people from Bangladesh. North Africa and the Balkans represent the largest shares. The Bangla is a particular phenomenon of the capital and Lazio, and is not yet studied or at its very beginning.

Indeed, the political legitimacy for representing Islam in Italy with the state is at stake for several Muslim associations, since in Muslim communities some groups can benefit from market of donations and services like translations and all issues linked to Arab language. Italian converts were indeed the ablest to be visible in public opinion and to give voice to Muslims' concerns and be listened by the state. Some of them also proposed the re-opening of ijtihad, the interpretation of Scripture in light of spatio-temporal evolutions (Allievi, S. 1999; Lano, P. 2005).

The composition of Muslim immigrants is mixed, the vast majority is Sunni, but they are also divided along lines of social and linguistic identity: mono-ethnic mosques for kthuba in any ethnic language; the geopolitical cultural competition for the kthuba in Italian by some converts or different ethnic Muslims who intend to escape the Arabization or Arab protection of the practice and transmission of their religious meanings. The language question also intersects with securitizing attention of the Ministry of the Interior or the need for creation of local political consensus. 
Moreover, many Muslims are also firstgeneration immigrants and speak only a bit of Italian. This factor along with ethnic variability leads to fragmentation, heterogeneity, and congregation according to national affiliations. In Italy, there is a certain discrepancy between the fact that the only mosque recognized as a charitable organization (Ente Morale) by the state is the Mosque of Rome (the largest in Europe until 2012), which originated with the support of Saudi Arabia, and the geopolitical and cultural gravitation from the Sunni Gulf area (despite developments coming from Moroccan Islam) and the fact that the majority of the faithful people are of Moroccan origin. This is the subject of contention and rebalancing in the legitimacy game to represent the interests of Muslims in Italy vis à vis the Italian State.

There is a striking political will not to legislate in order to ensure that the Muslim community is inserted adequately into the Italian social fabric. And this comes from a declared ideological aversion by a not irrelevant fraction of the political world against Muslims/immigrants, who strongly opposes any form of legal recognition of Islam in Italy. To date, the only recognized worship institution as a legal entity to the terms of the Law on 'allowed' cults (the law dates to the fascist period) is the Islamic cultural centre in Italy. There are four official mosques in Italy in the sense of ad hoc-made constructions, complete with minaret: Ravenna, Rome, Colle Val D’Elsa, Segrate Milan.

A second major discrepancy is the weight of (Italian) converts in interlocutions with the public (state, cultural production, translations, publications), who are in charge of relations with media and local Islamic centres (the public face of Islam) but not in charge of spiritual leaderships (amir) in mosques. This is of relevance for Italy and with national difference for Europe at large (Allievi, S. 1999).

In order of opening, while there are more than 1,000 Muslim places of worship, the location of mosques includes four in the North, two in Central Italy, and three in the South. Five mosques were opened in 2012 and 2013. The recent mosques have been financed by Qatari sources.

\section{Associations and representation of Islam}

Regarding Muslim associations, Islam in Italy does not have a single representative institution. Numerous associations claim to represent the interests of Muslims who live in Italy. According to the website www.arab. it (quoted in Nigrizia 2015, 24-25), the number of mosques and Islamic centres in Italy is 205, distributed throughout the peninsula. Of these, only 10 are registered as mosques in all respects, while 7 have the name 'Mosque and Cultural Center'. 57 sites of worship and cultural centers have been registered officially between 2013 and 2014. The cities with the greatest increase are Rome and Bologna. Several Islamic organizations claim to have the role of representative of Muslim interests. The most important numerically are the Center of Islamic Culture of Italy (Cici) and the Union of Communities and Islamic Organizations of Italy (Ucoii). Between these two organization there is a strong polarization and a quasi-absence of dialogue, stemming from their respective ideological positions (Lano, P. 2005; Bombardieri, M. 2011; El Ayoubi, M. 2015). The Islamic centre is linked to Saudi Arabia; the Ucoii is in the sphere of influence of the Muslim Brotherhood, from Qatar and hated by the Saudi government. Cici and Ucoii not only struggle for representation of the Islamic community but also for control of the hundreds of prayer rooms scattered throughout the country.

Among these associations of 'mosques Islam', multinational and multi-ethnic (LANO, P. 2005; Bombardieri, M. 2011). Only the largest or influential is quoted here: UCOII, close to the Muslim Brotherhood; the Muslim World League, with Saudi influence; COREIS is a community only of Italian converts to Islam, one of the principal interlocutor with the State. Other associations gathering ethnic diversity and gender issues (again linked to different 'Islam' origin approaches).

Next to 'Islam of the mosques', several observers reported the existence of an 'Islam of States' in Italy: countries such as Morocco, Egypt, which are worried about Saudi in- 
fluence and the Muslim Brotherhood, have organized themselves to follow its nationals abroad and to delegate representation to grassroots organizations at risk of becoming fundamentalist. There are also smaller Islamic sects with their own associations (ZANNINI, F. 2013).

In 2005, Interior Minister Giuseppe Pisanu appointed a 'Council for Italian Islam' (socalled Islamic Council), composed of 16 members, half of them Italian citizens, including members of both the cultural and the secular Muslim associations as well as leaders of religious associations.

\section{Discussion}

The Italian experience with Islam is rather unique compared to other larger European countries, since growth in the Islamic population and migration are a relatively recent phenomenon. This is also the key to the interpretation of the state policy towards the issues posed by the Muslim world in Italy.

Another influencing factor is the fact that except for people coming from the Horn of Africa, migrants do not come from countries with a past colonial relationship with Italy. In this respect, Italy is more similar to Germany, or to Hungary (PAP, N. et al. 2014) than to France or the UK. However, some recent intransigent or terrorist versions of Islam deliberately use the word and category of West or Infidels to categorize non-Muslims (or different sects of Muslims) as an enemy and dehumanize them.

According to influential commentators in Confronti (2015) and Nigrizia (2015) journals and associations, the integration of Muslims into the society certainly passes through an advanced integration model by the state (policies, school); nevertheless, Islamic worship places can play a decisive role in this direction as aggregation and socialization places and, as such, can affect those who attend them. It can also be added that more attention and efforts should be put on non-religious NGOs and other actors and their role in integrating migrants into the social fabric.
The mosques' role can be negative or positive, vis à vis the receiving country. The negative role of mosques occurs when they tend to marginalize the community by preaching hatred and contempt for the host society. So, those who attend them isolate themselves and avoid contact with outsiders, because the 'others' are considered hostile to Muslims. Another negative role of mosques (or families one would say) is when they perpetuate and reinforce gender segregation and the marginalization of women as a minority within the minority (Photo 2).

As IAnnucci, M. (2015) discusses the 'geographic approach' to mosques as a place of power reproduction but misunderstood or taught under the 'religion' imperative (own translation):

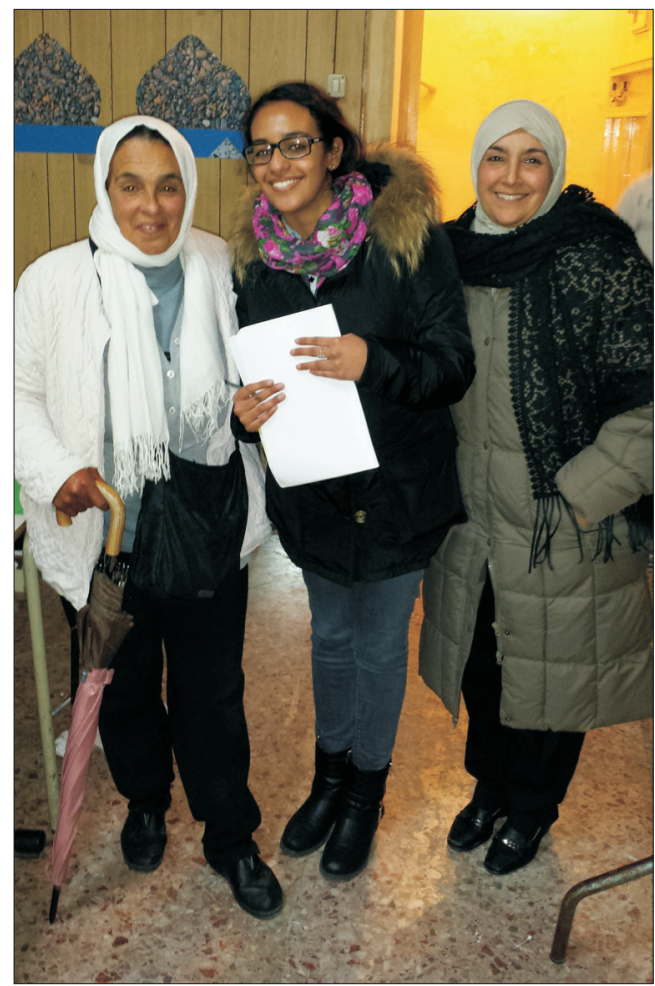

Photo 2. Generations of Muslim women (Photo by Paradiso, M.) 
'Multiculturalism of these Muslim communities is definitely a positive factor, but difficulties stemming from the imposition of non-shared models that affect religious practices have to be overcome. This is the case in the mosques, where the leadership is predominantly foreign, and this involves the persistence of cultural patterns - religious, but also management and participation - which hardly accommodate indigenous Muslims. In particular, women are often facing a vision of gender relations - in contrast to the role of women in the community and society generally - based on the very patriarchal and sexist culture of many Muslim immigrant communities. The macho culture is a common feature, and the leadership of Islamic centers is entirely male. The operating revenue, the smallest and residual places are reserved for women, who have a marginal role in the centers' activities and must be limited to targeted initiatives focused on the same women and children. These spaces are organized in a manner that facilitates segregation, with plenty of walls, tents and the like between men and women, which prevents the faithful from fully enjoying religious and cultural activities' (IANNUCCI, M. 2015, 57).

This occurs, for example, when the imams come directly from Islamic countries, ignorant of the language and culture of the context in which they preach, and they sometimes convey negative messages against non-Muslims. This happened, for example, in the Grand Mosque of Rome on June 6, 2003, when a young Egyptian imam, during kutbah (sermon) on Friday, launched anathemas against 'the infidel', Christians and Jews. Following the strong controversy raised by this case, the preacher was sent to Egypt by the heads of Cici. Quoting again IANNUCCI (own translation):

'Delivering (to practitioners) a vision of Islam that has at its center human dignity and freedom is a tool to combat discrimination and Islamophobia, as well as the religious fanaticism that can captivate youth in our country, if they continue to live in what apparently is a cultural vacuum in the community, but in reality is bridged by an increasingly Muslim vernacular sub-culture among migrants: patriarchal, self-referential and repetitive, impervious to dialogue and change' (IANNUCCI, M. 2015, 57).

The problematic aspect of the mosques is related to the training of imams, which is often improvised, and lacking rigor theologically and in other respects. In many cases imams do not know the Italian reality and do not speak Italian, or poorly. The sermons are given in the language of the preacher and Arabic predominates even when the mosque is attended by Senegalese, Turks or Pakistanis ... This has encouraged the flourishing of 'ethnic' mosques in Rome. The Italian language is sometimes used to summarize a Friday sermon to the faithful non-Arabic speaking people. A problem is seen in the training of imams: in Italy this is something claimed by converts with the only exception of Naples where some imams are not foreigners and where multiculturalism has a long time tradition (Photo 3).

The unresolved questions in Italy and at large with different nuances as well in many European countries concern: the State approach in integrating Muslims into the social fabric; the right to freedom of worship; the 'problematic' aspects of mosques; the theological issues concerning hermeneutics of Scriptures and 'ijtihad' reopening; internal issues within the broader Islamic community and third countries' interference in their social life and religious identity (Allevi, S. 1999, 2012; Gritti, R. and Allam, M. 2001; Bombardieri, M. 2011; NAso, P. and Salvarani, B. 2012; Naso, P. 2013; Zannini, F. 2013; Idos, Unar and Confronti 2015);

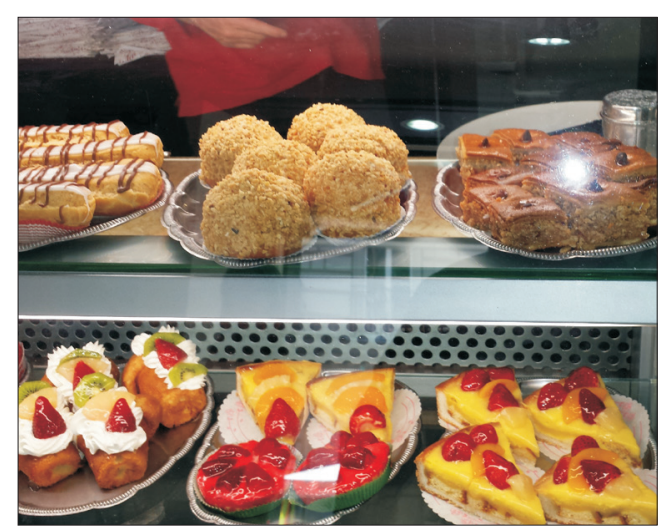

Photo 3. Multicultural confectionery in Naples at the Central Railway Station (Photo by PARAdiso, M.) 
the issue of a sexist and patriarchal influence of country of origin injected in immigrants' mindset and misunderstood as being part of Islam per se; the issue of converts and their dialectic for 'ijtihad' and their international networking. Furthermore, recent manipulation or propaganda stemming also from individuals, associations or non-State entities such as terror groups, via the Internet, complicate geopolitical struggles and promote violence and death. Satellite TV from Arab countries has been playing a role over the years in the information and opinion making realms and is serving geopolitical as well as cultural realms.

Religious freedom is not really assured as in many European countries. Actually, in Italy there are other elements that explain the issue of the freedom of worship and, properly, religious liberty at large: the legacy of the Fascist period in terms of laws which define the freedom of worship that remains a Ministry of Home Affairs task; Parliament's inability to reform the legislative framework on the subject due to vetoes that occur every time when there is a law proposed on the topic; the political discourse of some formations, especially the Northern League, a partner in many national governments in recent years and head of regional governments, which solicits the citizens' emotions in terms of migrant invasion, Eurabia, Islam as a religion of conquest and holy war. This has motivated a political approach which delegates to the local level approval of criteria for the opening of mosques; actually, the criteria that often prevents the opening of mosques.

Thus, geographies of religious practices consist of a misleading and not evident landscape of cultural associations. They are often located in claustrophobic spaces which may expand feelings of frustration and isolation. Often their leaders are not trained as imamsnor along which law or democratic procedures the leadership arises; permits to open mosques are highly variable around the country. These circumstances can drive concerns about ongoing problematic situations involving unclear power formation and reproduction in religious communities.
In Italy, in contrast to UK for example, the right of freedom of worship (or better religious liberty) is guaranteed by the Constitution but in practice it should be regulated by an agreement with the State which is on its way. This is a pending issue not only with Muslims but with other religions.

The conflicting Muslim associative world in itself for its internal diversity, pressures from outside and emancipation trends raised by converts and native Muslim people are seen as the salient elements of Islam in Italy (GRITTI, R. and Allam, M. 2001; Naso, P. and Salvarani, B. 2012; Bombardieri, M. 2015). Recent trends show less pressure and it is clear that the State will not give supremacy in representing Muslims in Italy to any association. Thus, the Muslim struggle is driven by the broader action of a religious freedom law gathering all religions still waiting for an Agreement with the State.

Many places have numerous unresolved issues concerning prisons, mosques, schools, and cemeteries. The vision of religious pluralism in Italy is that of a yard with no project (Naso, P. and Salvarani, B. 2012). Conversely, the approach is one of creation of platforms for dialogue, first promoting active pluralism, a 'good' pluralism not a 'bad' pluralism (not multiculturalism as in the UK) (NAso, P. 2013). It is aimed at involving intermediate actors in the public discourse, as a civil dimension of interreligious dialogue. However, reality can be different: increasing support to religious NGOs is evident and it is far less evident that one to civil non-religious society in the dialogue. Finally, a growing weight in relations with the state and society is ensured by the growing number of converts and also with international realms.

According to the journal Confronti (2015), an authoritative think-tank and publication venue for interreligious dialogue, religion, politics and society, Muslim people in Europe can be influenced by the geopolitical situation in the Islamic world at large, and the Arab world in particular. The lack, in many European countries, of legal protection and appropriate policies for healthy integration of Muslims, exposes them to recent interfer- 
ence in their religious life from Arab-Islamic regimes. Non-governmental Islamic organizations, through financial support to communities, tend to directly or indirectly exercise religious and political control over them. For example, the Qatar Charity in recent years has provided several million dollars in funding to build mosques around Europe. The same applies to NGOs supported by Saudi Arabia and other Arab Gulf countries. These countries are known to have a marked aversion to the democracy and secular values of with some imperfections - Western countries. This interference, under the eyes of European governments, does not help the Islamic communities to achieve a 'healthy' growth and to develop a European vision of their faith, El Ayoubi, M. (2015) summarizing an Italian interreligious debate.

\section{Conclusions}

This paper argues that we need to avoid unpacked and overwhelming categorizations. Instead, we should use a geographic approach in terms of fixity-mobility dialectics and origin-destination-circulation scales of shaping places, networks, and ideas.

First, the paper pointed to 'human subjectivity' and intersectional identity as a first element of interpretation and engaged policies. Then, the influence of the country of origin was discussed and it was called as an ethnic factor. This relates to other geographical elements of interethnic relationships globally and locally, from the interethnic mosque to the home realm. The country of origin is often conjugated with a religious and political cleavage in terms of Islam traditions (wahnabism, Sufism) and geopolitics of States for Islam(s) in Europe. Then, the paper focused on issues of 'geographies of mosques': Are they externally controlled and financed? How much do they represent people migrated to Europe?

Based on an overall approach in terms of 'subjectivity and human factors', ethnic variation and interethnic and intra-faith relation- ships (geopolitics of mosques and States), the paper disclosed issues of quests and competition for legitimacy of representation with the European State and margins of being or becoming political actors in Europe.

The boundaries of political communities may frame a discussion which stems from some central issues: Who are Muslims in Italy or Europe? What about their identity building along different cleavages and belonging (intersectionality)? What about differences between 'new Muslims' (converted) and born Muslims? What about future generations of Muslim people in Europe? What is about the dialectic of Muslims of Italy and origin religious tradition?

One thesis is that of European Muslims (the 'converted') who 're-culturalise' by integrating new ideas from a cultural world 'other' in a previously 'Western' background (Islam 'occidentalement' - VAN DER BROECK, L.O. 1990; Allievi, S. 1999). Another thesis is of Islam as an ideology of resistance not only in a post-colonial frame but in terms of European marginalized people being abandoned in a welfare State in crisis or under increasingly corrupted politics. Thus, people may be motivated to escape into Islam as an oasis of 'purity', as an occasion of salvation, safety, redemption, escape, anchor, refuge. Finally, more efforts should be put into dialogue and based on the involvement of nonconfessional civil society strata.

Today, it is necessary to address the issue of training imams in Italy with adequate theological and linguistic preparation: a training which takes into account the Italian social, cultural and legal context. 'Good' mosques and well trained imams are needed to ferry the Islamic reality towards an integrated Italian Islam that remains strongly based on its Koran spirituality and the Sunna, but that is capable of facing without fears reforms which the religion needs (see special issues: Confronti, 2015; Nigrizia, 2015). From the Italian interreligious dialogue and individual intellectuals, the thesis for integration is about Islamic doctrine in the practical not theoretical) sphere of human rights, etc. 
In Italy, as elsewhere in Europe, conditions of democracy and freedom of worship and expression prevail. They may allow Muslims to reopen the gates of ijtihad (Hermeneutics) and then the contextualization of the main sources of Islam, namely the Qur'an and the Sunna. A modern Islam and a reformed one according to the Italian interreligious dialogue debate is the remedy for diseases of fundamentalism/Jihadism and Islamophobia/xenophobia of which Muslims today are the first victims.

The challenges that concern primarily Muslims also concern institutions and civil society, who have the civic duty to promote this difficult process of building a multi-religious society where Muslims and their faith can find adequate 'citizenship'. This should not be left only to religious associations, interreligious dialogue in itself or communities of faith. Bridges among people in civil situations and places are really needed (universities, school activities, non-religious NGOs, women involved in multi-ethnic activities and realms).

Issues of Italian language teaching for women and men, attention to equal opportunities, multi religious, and non-religious multi-ethnic realms should be forcefully pursued. Self-caged communities and non-Muslim no-go zones are an obstacle for gaining opportunities and status by Muslims. Finally, the lack of integration, rising Islamophobia, and xenophobia, are also linked to the diminution of the Welfare State creating new poverty among Europeans, thus, causing deviance and intolerance, among other outcomes.

Again, the keys to achieving and maintaining well-being are the human factor and identity building which increasingly are made more difficult by adverse material conditions, ignorance, and fears on both sides: new Europeans or hosted people and 'old' Europeans. Identity is an intersectional process, and the weight of a single cleavage cannot be determined a priori (Sen, A. 2006; Malouf, A. 2010). The problem lies in contemporary societies with a schizophrenic approach: being exposed to global communication and information, but being educated, raised, and nurtured as 'small' hu- man beings (SeN, A. 2006). Fundamentalism is indeed a 'political' 'party' with a solid financial basis often obtained via crime and geopolitical influence; conversely, individuals hardly or do not find nationally responsive politics and politicians.

Agencies for open discourse, integration, and bridging gaps between people have no solid financial basis or media attention. Warfare police surveillance, martial law thus can become a temptation in European States, as can walls against refugees' families and people in search of peaceful conditions for life.

The European tradition of human rights, universalism, and democracy should be reexamined and practiced not only in the abstract but in the concrete of engaged human relations with 'empathy' while avoiding the laissez faire of multiculturalism, demagogic 'hate' discourse and xenophobia, aggressive assimilation or 'culturalism' exceptions.

\section{REFERENCES}

Allievi, S. 1999. New Muslims. The converted to Islam. Roma, Edizioni Lavoro. (Italian)

Allievi, S. 2012. Islam in change and not changing Islam. In Italy of Religions. A construction site without a design. Eds.: Naso, P. and Salvarani, B., Bologna, EMI, 98-115. (Italian)

Berger, P.I. 1969. A rumour of angels. Modern Society and the rediscovery of the sacred. New York, Doubleday.

Bombardieri, M 2011. Mosques of Italy. Bologna, EMI.

Bombardieri, M. 2015. The Mosque: place of prayers and socialization. Confronti, Special issue, 5-6. June 2015.

Confronti 2015. Minarets and Dialogue. Confronti, Special issue, June 2015.

Cresswell, T. and Merriman, P. 2011. Geographies of Mobilities: Practices, Spaces, Subjects. London, Ashgate.

DAtтA, A. 2009. 'This is special humor': visual narratives of Polish masculinities on London's building sites. In Polish Migration to the UK in the 'New' European Union: After 2004. Ed.: BurrelL, K., Aldershot, Ashgate, 189-210.

El Ayoubi, M. 2015. The Challenge of Italian Islam. Minarets and Dialogue. Confronti, Special issue, 2-4.

Eккнаме, P. 2016. Geography of Migration I. Refugees. Published online August 29, 2016. Progress in Human Geography 1-10. doi:10.1177/0309132516663061 
Eva, F. 2012. Caging/self-caging: materiality and memes as tools for geopolitical analysis. Human Geography 5. (3): 1-14.

FARINELli, F. 1998. The Mediterranean, the difference, the deferment. Geotema 12.57-62. (Italian)

Gritti, R. and Allam, M. 2001. Islam, Italy. Who are and what Muslims living among us think. Roma, Guerini e Associati. (Italian)

Hyndman, J. and Giles, W. 2016. Refugees in Extended Exile: Living on the Edge. London, Routledge.

IANNUCCI, M. 2015. Muslim women under marginalisation. Nigrizia 6.55-57. (Italian)

Idos, Unar, Confronti 2015. From Discrimination to Rights. 2015 Migration Report. Roma, Idos Research Centre. (Italian)

Kellerman, A. 2006. Personal mobilities. London and New York, Routledge.

Kocsis, K., Molnár Sansum, J., Kreinin, L., Michalkó, G., Botтliк, Z. Szabó, B., Balizs, D. and Varga, G. 2016. Geographical characteristics of contemporary international migration in and into Europe. Hungarian Geographical Bulletin 65. (4): 369-390.

Lano, P. 2005. Islam of Italy. Roma, Edizioni Paoline. (Italian)

Malouf, A. 2010. Les Identités Meurtrières. Paris, Librairie Générale Française.

Montanari, A. and Paluzzi, E. 2016. Human mobility and settlement patterns from eight EU countries to the Italian regions of Lombardy, Veneto, Tuscany, Lazio and Sicily. Hungarian Geographical Bulletin 65. (4): 331-344.

Naso, P. 2013. Old and new religious pluralism in Italy. In Vademecum: Religions, dialogue, integration. Ed.: Ministry of Home Affairs, Republic of Italy. Roma, Ministry of Home Affairs, 37-46. (Italian)
Naso, P. and Salvarani, B. eds. 2012. Italy of Religions. A construction site without design. Bologna, EMI. (Italian)

Nigrizia 2015. Dossier Islam in Italy. Nigrizia, Special issue. Ed.: Al Ayoubi, M., June 2015. 42-60.

Pap, N. and Glied, V. 2017. The Hungarian Border Barrier and Islam. Journal of Muslims in Europe 6. 104-131.

Pap, N., Reményi, P., Csaszar, Z.M. and Végh, A. 2014. Islam and the Hungarians, Mitteilungen der Osterreichischen Geographischen Gesellschaft 156. 191-220.

PARAdiso, M. 2013. The Role of Information and Communications Technologies in Migrants from Tunisia's Jasmine Revolution. Growth Change 44. 168-182.

SEN, A. 2006. Identity and Violence. The Illusion of Destiny. Bari, Laterza. (Italian)

VAlentine, G. 2007. Theorizing and researching intersectionality: a challenge for feminist geography. The Professional Geographer 59. 10-21.

VALENTine, G. and SADGROVE, J. 2012. Lived difference: a narrative account of spatiotemporal processes of social differentiation. Environment and Planning $A$, 44. (9): 2049-2063.

VAN DER BRoeck, L.O. 1990. Islam occidentalement? Ghent, Communicatie \& Cognitie.

ZANNINI, F. 2013. Islam in Italy: mapping, paths, processes. In Vademecum: Religions, dialogue, integration. Ed.: Ministry of Home Affairs, Republic of Italy. Roma, Ministry of Home Affairs, 57-69. 
